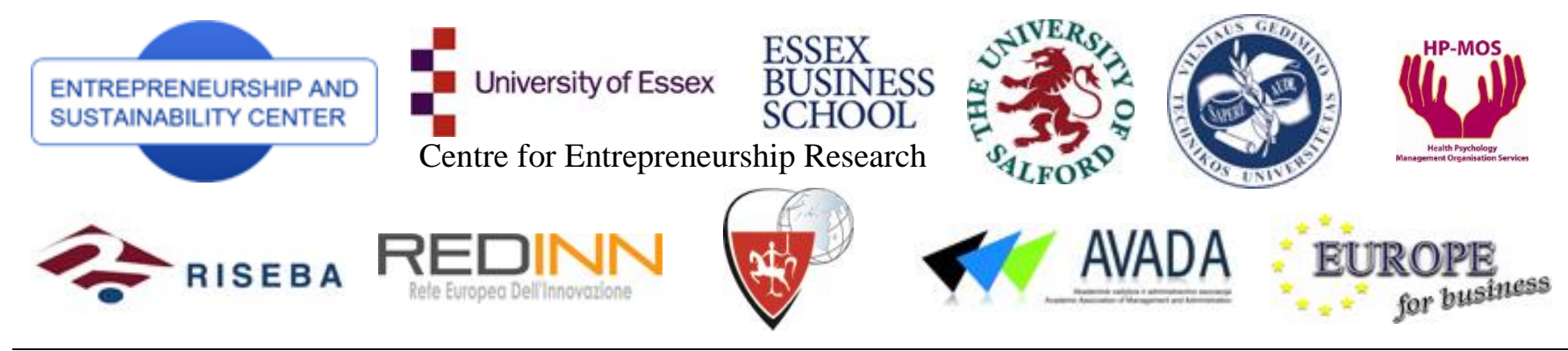

ENTREPRENEURSHIP AND SUSTAINABILITY ISSUES

ISSN 2345-0282 (online) http://jssidoi.org/jesi/aims-and-scope-of-research/

\title{
PUBLIC SECTOR CONTROL AS A FACTOR IN ENTREPRENEURIAL POLICY: THE CASE OF LITHUANIA
}

\author{
Mantas Bileišis \\ Mykolas Romeris University, Ateities str. 20, LT-08303 Vilnius, Lithuania \\ E-mail: mantas.bileisis@mruni.eu
}

Received 25 October 2012; accepted 10 January 2014

\begin{abstract}
The paper describes the development of the Lithuanian public sector control in an attempt to evaluate how its changes affect possibilities for entrepreneurship both in the public and private sectors. An analysis of change of functions, organization, and regulation over the period of past two decades is done to see how the philosophy of public sector control in Lithuania evolved and how this changed the practices of control. The data for analysis is derived from legal documents and relevant institutional reports. Controlling the public sector has usually been about democratic accountability. Currently this layer is supplemented by attempts to advance best practice in terms of efficiency. Over the past 20 years Lithuania has undergone a path similar to the one described above. As a result, however, Lithuanian public sector control system has grown in complexity and became more bureaucratized. Attempts at increasing entrepreneurship in the public sector are often matched by increased control. This paradox of increased control produces greater bureaucracy and this risks limiting entrepreneurship in both private and public sectors. And this needs to be taken to account when designing pro-entrepreneurial policies.
\end{abstract}

Keywords: Public sector control, control institutions, Lithuania, public governance.

Reference to this paper should be made as follows: Bileišis, M. 2014. Public Sector Control as a Factor in Entrepreneurial Policy: the Case of Lithuania, Entrepreneurship and Sustainability Issues 1(3): 151-161.

DOI: http://dx.doi.org/10.9770/jesi.2014.1.3(4)

JEL Classifications: D02, H83

\section{Introduction}

Control is a term that has many definitions which vary considerably depending on the context/academic discipline it is used in. This article presents an overview of difficulties of conceptualizing public sector control, and also an analysis of challenges in the Lithuanian public sector control with regard to proentrepreneurial policy. It is proposed to define control in the public sector by analysing its relation to the underlying principle of organizing public sector - that of democratic mandate. There are several arguments why a normative theory of the state appears unwanted without an idea of democratic mandate. And even the worst types of totalitarian dictatorships attempt presenting themselves as democratic (e. g. North Koreas' official title is Democratic People's Republic of Korea). However, such examples also indicate that practice and rhetoric are not necessarily consistent in issues related to politics. The article identifies three interpretations of the state (within the framework of democratic mandate) which serve as a theoretical prism through which we can evaluate the development of public sector control mechanisms. In this article they're referred to as "budgetary", "national" and "field". The three interpretations are identified by their differences 
in how they would answer the questions of (i) whether the states ought to be treated as some sort of metaorganization, (ii) what are the measures of success in the public sector, and (iii) what are the purposes of the state?

One particular feature of the Lithuanian state is that it formed after a 50 year interruption caused by soviet occupation at a time when much of public governance research observed a substantial (some even went on to describe it as paradigm) shift in the way political elites and academic mainstream would've answered the above questions. On the other hand the revolution of 1990 did not dismantle the administrative apparatus created in the period of occupation. Thus the analysis of public sector development in this region is a complex question of post-communist transition, interbellum revivalism, and of the changing conception of role of the public sector. This complexity means that the development of the Lithuanian public sector control had to respond to multiple factors, many of which were driven by local considerations, at the same time increasing participation in the global economic order placed demands on the state from the outside.

The article presents the dynamic of control mechanisms in the Lithuanian public sector over the past two decades and identifies key factors driving changes in how public sector control is exercised. It is observed that changes in public sector control are often implemented by presenting them as part of "entrepreneurship friendly" policy, but their outcomes do not necessarily that. Several factors can be identified that must always be considered such as agency autonomy, performance evaluation/appraisal, and historically contingent organizational and legal complexity.

\section{Analytical framework: subjectivizing control of public sector organizations}

There are several events that are usually debated under the rubric "globalization" throughout the social sciences. M. Castells (2006) goes on to suggest that the technology induced changes in the way we go about business and politics have brought the Soviet system down as part of the greater trend of globalization. His idea revolves around the fact that as the economy becomes ever more based on knowledge sharing across borders. And totalitarian systems such as the Soviet Union could not keep up. Opening the channels of knowledge sharing communication had not only an economic, but also an emancipatory political effect. Lithuania being a part of the post-communist Europe over fifteen years since its collapse has managed to fully integrate into the western economic and political order. This period has seen an unprecedented institutional change. But this also was not a clear cut process. First, a plethora of institutions has survived the revolution and adapted to the new political and economic regime. This, however, also meant that many of the soviet-period organizational and government practices also persisted. Second, the globalization process is often claimed to have changed the role of the state itself. Thus, Lithuanians having regained their state after a 50 -year break could not rely on their prior statecraft experience. This caused a lot of political friction among the political forces shaping the new state as it became apparent that the republic cannot be what it once was and as new visions began to arise of what it ought to be. Third, over the period since 1945 international organizations (especially in Europe) became a powerful factor in domestic politics, far beyond of what they were in the 1930's. Organizations that aided the restored republic such as the International Monetary Fund, World Bank, Organization of Economic Cooperation and Development and organizations Lithuania wanted to be part of such as the United Nations (and its subsidiaries); European Union (EU) and North Atlantic Treaty Organization had their say in how the countries government was shaped.

The analysis presented below revolves around three interpretations of state. All of these can be used as rhetoric tools when constructing arguments in favour of one or the other policy by politicians and other public officials. And they can also serve as an analytical prism when describing the development of the state. The three are referred to as: "budgetary", "national" and "field". Before presenting the three interpretations in detail two ideas need to be discussed: democratic mandate and control in the public sector. Both of these ideas are understood differently in every of the interpretations described in this article. The first, democratic mandate is inseparable from what we define as the modern state in the context of western academia ${ }^{1}$. Democratic mandate can be traced the great early modern revolution in France and United States (U.S.) whose ideals were based on secular values. The democratic mandate being one of the core social ideas of the

\footnotetext{
${ }^{1}$ The economic rise of China does lead some to speculate whether economic prosperity and democracy are inseparable, but democracy remains an uncontested value in the context of political and social science, often seen as the major achievement and distinctive feature of the Western civilization (for a discussion on China see Tsai (2007).
} 
Enlightenment was constructed in opposition to the divine mandate (divine right of kings), a theory whereby the right to rule was granted by the supernatural. In a situation where we cannot prove the existence of a supernatural the will of the people seems second best thing. But in practice identifying who "the People" are, what is their "will: and how do we select government is difficult and makes the democratic mandate a very complex idea. At the core of democratic mandate lies the idea of control. Without it democratic mandate becomes impossible. At its most abstract the ideas of periodical elections and division of powers are what serve to control the government so it acts within its mandate (Eagle 2008). Periodic elections ensure that the government accounts to the populace directly, while the division of powers artificially, through constitutionals provisions, creates tension (in the context of e.g. U.S. constitution referred to as "checks and balances") among the branches of government so that there is no single institution which could monopolize the state power and do away with fair and free elections (and other civic rights). Beginning with to define "the People" we will use the Lithuanian legal framework of how individuals who are in some sort of relation towards the state of Lithuania are defined. We can identify three groups of persons: Members of the Nation, Members of Local Communities and Residents. There are two criterions which allow identifying a person as belonging to one, two or all of these groups: fact of residency in Lithuania and possession of citizenship (see Table 1).

Table 1. Belonging to legal categories of persons depending on the citizenship and place of residence

\begin{tabular}{ccccc}
\hline & $\begin{array}{c}\text { Citizen living in } \\
\text { Lithuania }\end{array}$ & $\begin{array}{c}\text { Citizen not } \\
\text { living in } \\
\text { Lithuania }\end{array}$ & $\begin{array}{c}\text { Non-citizen resident } \\
\text { (After EU accession in } \\
\text { 2004) }\end{array}$ & $\begin{array}{c}\text { Non-citizen resident (Pre- } \\
\text { EU accession) }\end{array}$ \\
\hline $\begin{array}{c}\text { Member of the Nation } \\
\begin{array}{c}\text { Member of Local } \\
\text { Community }\end{array}\end{array}$ & Yes & Yes & No & No \\
Resident & Yes & No & Nes & Yes \\
\hline
\end{tabular}

Source: developed by author

From the position of constitutional regulation the possession of citizenship gives the right to participate in the democratic mandate, i.e. it is the citizens that are the primary participants in the democratic process and the ones that in the Lithuanian context can be referred to as "the People". Lithuania, being a small unitary state has only one other form of democratic government institution - the local self-government. The national and local levels are constitutionally separate; the national parliament only regulates by law the exact delimitation of the spheres of responsibility of the two. Although most individuals in the country are simultaneously members of all three legal categories, in practice there are people who pay taxes, but have no direct say in the way the country is run (on the national level). From the purely theoretical point of view this means that in the constitutional context the state transcends the economy and consequently policy makers are allowed or even expected to make decisions by having different considerations in mind.

As far as the idea of democratic mandate goes, "the People" (in the case of Lithuania: the Nation or the Local Community) are the ultimate principles of public sector control, meaning that the entire institutional, legal and organizational setup ought to, in principle, serve the purpose to inform the populace in a way that it could make best decisions on what policies are worth pursuing. However, here we run into a problem that the concept of control in the public sector is contingent on the way we interpret what the state is.

\section{Analytical framework: three interpretations of the state}

As a starting point for conceptualizing control within the public sector we can borrow from the classic (Fayolian) definition of management, where control is part of the management cycle among other managerial functions of planning, organizing, staffing and motivating (Rao and Kumar 2010). Within such a framework the purpose of control is one of feedback, whereby information is gathered about the processes taking place in the organization and it is measured against the desired situation. In this situation, the control ought to be conducted only in cases when there is an organizational plan and a definition of what is desired. And it is precisely here that we see a distinction between control in the private sector and the public sector. The public 
sector cannot be reduced to profit seeking, and in the context of democracy, where we have competing political ideas and government institutions, it is hard to claim that the state has a plan for itself against which it would be possible to control its performance. Also the subjects of control, "the People", are seldom aware of the multitude of plans generated by independent or semi-independent government agencies, while these agencies themselves seldom manage to plan in a way that is complimentary not contradictory to other public sector planning.

As we saw above the Lithuanian state is organized around the idea of the Nation and by its ideology we can suggest that it conforms to what we call a "national" interpretation of the state. This is characterized by ideas, that the People, i.e. the Nation, share a culture which implies certain collective aspirations and values which ought to govern their collective existence. And the purpose of the democratic process is to articulate and help implement these aspirations and values. This romantic conception is an underlying premise of most democratic constitutions, but it is neither the only nor a dominating interpretation of what a state may be. Despite there being a wild variety of ideas about the state we will present two alternatives which we consider to be sufficient for our analytical framework. Going back to the narrative of "globalisation", the ideology that drove economic policies which were seen as "speeding up" globalization such as greater liberalization of trade, deregulation, etc. is usually defined as neoliberalism. Neoliberalism saw its political rise in the 80 's, most notably in the U.S. during the terms of President R. Reagan and in the United Kingdom during the premiership of M. Thatcher ${ }^{2}$. Similar policies were advocated by western powers elsewhere through became known as "Washington consensus" (Petrovic 2013). One of the primary premises of neoliberalism is that the state is less efficient in terms of both economic activity itself and in terms of supervision of the economy. This implied that state owned corporations ought to be privatized, and the market ought to be deregulated (because it self-regulates better that the state ever could). Moreover, the state bureaucracy ought to be run in ways similar to those of the private companies. This last idea by 1991 began to be referred to as New Public Management (or NPM) (Hood 1991). As a result a shift towards conceptualizing the state in economic terms began. This shift required reducing the transcendental aspirations and values of nations to the individual profit motive. Within NPM we see a utilitarian discussion about the purpose of the government. One such attempt was Lane's (2001). By identifying different types of goods he constructed a theory, by which policy makers could determine which elements of production should be private and which should be public. Such a reduction allows for quantification of government output and a comparison with the private sector. Within the Western context we can see NPM beginning a pro-entrepreneurial trend not only towards the private sector, but also within the public sector by increasing organizational autonomy and creating motivation based on customer satisfaction.

NPM does not necessarily coincide with what we call the "budgetary" interpretation of the state. The concept of society as a purely economic structure can be traced to as far as K. Marx's economic determinism (Morrison 2006). We choose to call the second interpretation as "budgetary" because the main feature of policy within the economic conception of the state is that state policy is financed through budgets making it impossible to trace budget allocation to taxes paid. And that, following Lane (2001), in certain situations can be economically more efficient than market mechanisms. So far we can see that the "budgetary" interpretation within the ideology of NPM provides the basis of pro-entrepreneurial state policy. But the "national" interpretation does not necessarily is opposite to that. Simply it requires the populace to be supportive of such policies. As the writings of M. Weber (Kim 2004) suggest north-western European and North American protestant dominated countries had populaces which supported private endeavour. As NPM spread into the Lithuanian academe and as during much of the early 90's Lithuania received aid and support from international non-governmental organizations a "budgetary" reasoning became a permanent feature of policy design.

As we will see later within the Lithuanian context the above two interpretations of the state are difficult to reconcile. But the most serious hurdle to such reconciliation can be illuminated by a third interpretation of the state, one we refer here to as the "field" interpretation. We chose the term "field" following the writings of P. Bordieu (Grenfell 2008) and insights of New Institutionalism (Bileišis 2012a). One particular premise that unites the "national" and "budgetary" interpretations of the state is the idea that the state is a metaorganization serving a single ultimate goal. But already at the level of constitutional separation of powers we seem to intentionally weaken the state in such a way that it becomes almost impossible to identify it as an

\footnotetext{
${ }^{2}$ Both of these individuals had their neoliberal economic policies named after them: Raegonomics and Thacherism.
} 
organization. Furthermore civic participation in public matters means that the state-society division is also not as clear cut as may appear. Consequently we could describe the state as a "field" where various institutions juggle for power within a framework of rules. These rules allow institutions to compete at some levels and to cooperate at others. For example, we can define the family as an institution. However, identifying agents who would defend the interests of such an institution is rather difficult. That is because there are certain historically contingent rules which allow the institution of family to persist. These rules may be expressly regulated by law or maybe implicit in cultural practices. However, if there are attempts to redefine what family means, individuals who feel they have a stake in this institutions would associate themselves in either defence of the "traditional" family, or support of the "modernization" of family (e.g. gay marriage, polygamy, ect.). In such an interpretation the state can be seen as an institution at one level, at which it gives legitimacy to a multitude of government organizations while at the same time individual public organizations can be seen as competing institutions. For example, police and social services may compete for the same funds when allocating budget by claiming that their respective institution have greater impact on public safety. Thus, the "field" interpretation allows us to see a level of complexity when talking about public organization control that the other two cannot.

Table 2. Three interpretations of the state

\begin{tabular}{|c|c|c|c|}
\hline & Bugetary & National & Field \\
\hline Is state an organization? & Yes & Yes & No \\
\hline $\begin{array}{c}\text { What is the measure of states } \\
\text { success? }\end{array}$ & $\begin{array}{l}\text { State creates added value and } \\
\text { contributes to the growth of } \\
\text { the economy }\end{array}$ & $\begin{array}{l}\text { Sence of (and satisfaction } \\
\text { with) national identity in the } \\
\text { society }\end{array}$ & $\begin{array}{l}\text { Success is relative. There are } \\
\text { "winners" and "loosers" }\end{array}$ \\
\hline $\begin{array}{c}\text { What is the purpose of the } \\
\text { state? }\end{array}$ & Economic efficiency & $\begin{array}{l}\text { Defence (and articulation) of } \\
\text { national/public interest }\end{array}$ & Survival and power \\
\hline
\end{tabular}

Source: developed by author

In the field interpretation control becomes separated from legal category of citizen, member of community, or resident. Rather an individual can be a representative of a multitude of institutions, which can be conflicting amongst themselves. And in this interpretation each institution tries to create both internal and external control mechanisms to keep descent within and competition without at bay. This, when talking about the state institutions, means that stated policy aims may quickly be hijacked by narrower institutional interest. The presentation of the Lithuanian case bellow allows us to hypothesize that not only the reconciliation of "national" and "budgetary" narratives is needed for a cohesive, sustainable and successful pro-entrepreneurial policies are needed. Also there needs to be a greater understanding of the intricate mechanisms of control which limit how successful a given policy may be (see Table 2 for a comparison of the three interpretations).

\section{Conceptualizing public sector control: the Lithuanian case}

There are two institutions that are referred to as "control" in the Lithuanian Constitution. One is the National Audit Office of Lithuania, which in Lithuanian is called "State Control" (lith. Valstybès kontrolè). This office initially was an organization which supervised budget expenditures of the executive for the benefit of the parliament. Only in the late 90's Offices' main mode of functioning was changed from financial review to financial audit, in early 2000's this was complimented by performance audit. These changes occurred both as a result of Offices' participation in INTOSAI/EUROSAI ${ }^{3}$ and EU community law requirements during the Lithuanian accession process. The original function of the National Audit Office (which remains its core function) is to present information to the parliament about the way the executive uses budgetary funds so that the parliament can take rational decisions regarding regulation. Also if the Office identifies possible illicit activities by government agencies it can refer the information to the Prosecutor's Office. The second control institutions are the two Ombudsman's Offices (in the Lithuanian Constitution called Parliamentary Control

\footnotetext{
${ }^{3}$ INTOSAI stands for International Organization of Supreme Audit Institutions. EUROSAI is its regional European subdivision.
} 
Officers, lith. Seimo kontrolieriai), one charged with citizen complains about bureaucratism ${ }^{4}$ in the municipalities, the other - at the national government level.

By adding the two institutions to what we described above when talking about the idea of democratic mandate present in the Lithuanian constitution, we get a basic scheme of how the public control is institutionalized in Lithuania at the national level (See Figure 1). At the local level there is a more complex control system. On the one hand municipalities themselves have audit offices and a dedicated Ombudsman, on the other the National Audit Office and the executive (Government of Lithuania/Cabinet of Ministers ${ }^{5}$ ) add another layer of municipal supervision. There are 10 insititutions (dedicated to groups of municipalities organized into counties) of Government Representatives Offices which oversee that national regulation is adhered to at the local government level (See Figure 2).

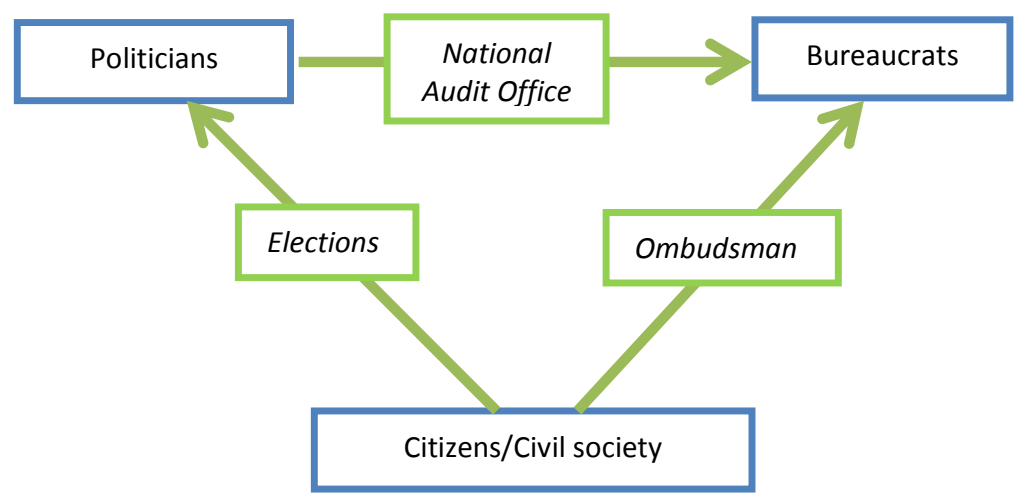

Fig.1. Basic constitutional scheme of public sector control at the national level

Source: developed by author

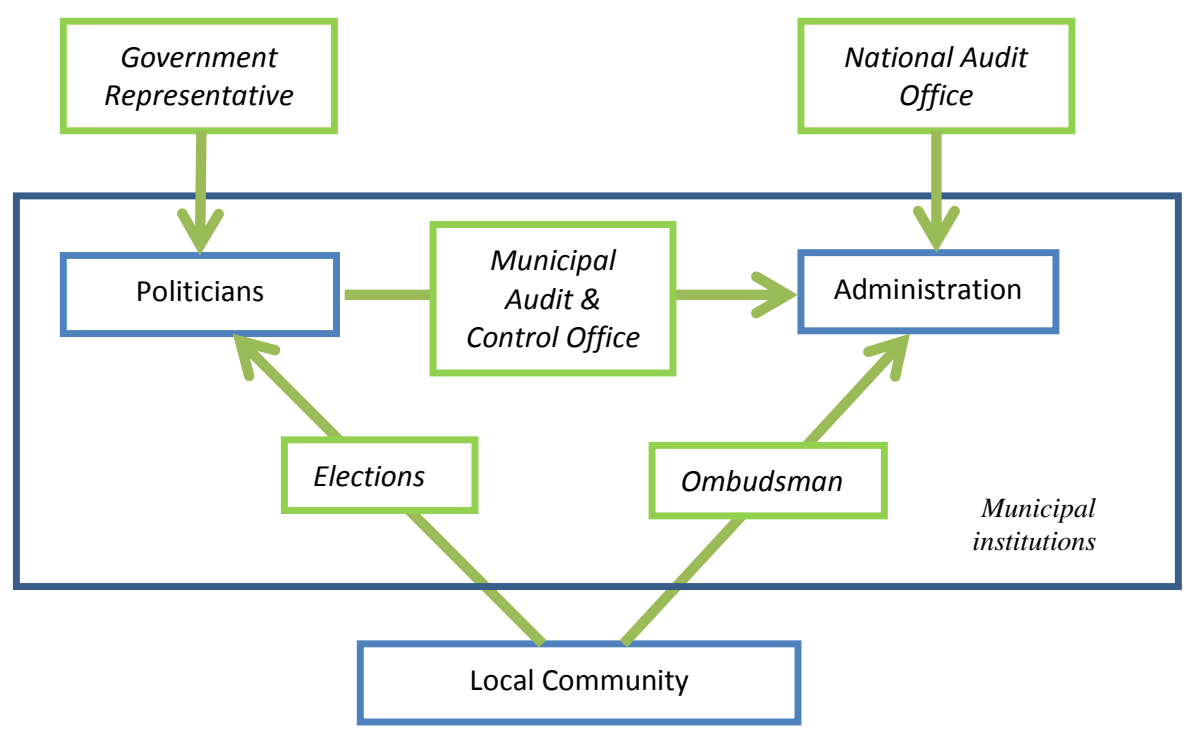

Fig.2. Basic constitutional scheme of public sector control at the municipal level

Source: developed by author

The mechanisms we have described had its basic form at the National level since the adoption of the current Constitution in 1992 and the Government Representative's institutions were created when the county system

\footnotetext{
${ }^{4}$ Lithuanian Law of Ombudsmen (Parliamentary Control Officers) defines a term bureaucratism (lith. biurokratizmas), which is understood as a perversion of the public office by abusing administrative discretion to stall or impede administrative process.

${ }^{5}$ Please note that in the Lithuanian Constitution the Govenrment and the Cabinet of Ministers are one and the same thing. Whereas to describe the entire system of state institutions Lithuanians use a hard-to-translate word valdžia. This double use of the term government when talking in English may be confusing.
} 
was setup in 1995. The one feature of the control mechanisms described here is that they mostly are concerned with ensuring that state institutions are responsive and accountable to "the People" and to each other, which is needed for the "checks and balances system" to function properly. That is if we for the time being accept the state-society division (for a detailed discussion see Midgal 2001) than this is the control mechanism that is organized to attempt to ensure societies overview and the overview of top political institutions (Parliament and the Ministers office as well as Municipal Councils) over public bureaucracies.

But the main body of control in the public sector goes the other way. It is the public bureaucracy institutions tasked to supervise the social and economic activity that make up the majority of public sector control functions. We still lack an integrated list of these organizations in Lithuania and this paper does not attempt to fill this gap ${ }^{6}$. Nonetheless within regulation we can identify a variety of principles that guide control. In the public sector and these principles can be evaluated against management theories that conceptualize control.

Before starting our overview of the Lithuanian public sector control system we need to spell out the implications of what is said above. We can see that there is multiple feedback loops in the public sector to all of which we can be referring to as control. The public control the legislative, it controls the policies of the executive, and the executive controls its agencies and municipalities. On top of that there is a layer of control institutions, which have a varying degree of autonomy from either the executive or the legislative and are tasked to perform control over each other and the broader society. One observation that arises is that no one person/institution can evaluate whether the entire state machinery works in unison and whether it is fulfilling its goals. There are two mechanisms in the Lithuanian regulation which are supposed to aid in dealing with this problem. First, it is the idea of rule of law which demands adherence to due process, proportionality and adherence to regulation at all times in all public activities (Palombella 2010). But going by the principle of the rule of law alone raises a demand to expressly identify what the public/state interest is and that admittedly is hard to come by. Lithuania does not have an express definition of the public interest and leaves it to the practice of the courts to incrementally figure out. In practice this means that the democratic ideal is side-lined. Going back to our interpretations of the state, the idea of the rule of law with its implied possibility to create and amend the content of laws through the democratic process is clearly closest to what we could call the "national" interpretation with the national interest being what we above called nations values and aspirations. The second mechanism is being developed since 1999 and is based on the introduction of strategic planning. However, the document regulating the hierarchy of strategic plans does not have the status of law; it is only a government regulation (Bileišis 2012b). Furthermore, there are no mechanisms that would hold agencies accountable for not attaining strategic goals. The only thing usually being accounted for is the use of finances. By this time Lithuanian public sector does have a strategic planning based budgeting system, but it is easily overwritten by political considerations due to the fact that strategic planning is seen as antagonistic to the principle of the rule of law.

A review of the laws providing a definition of control with relation to the public sector (budget law, internal control and audit (applied to public entities) law, insurance law, and national audit authority law ${ }^{7}$ ) allows us to identify the following aims of control from the perspective of the rule of law:

- legality;

- economy;

- efficiency;

- results;

- transparency;

- implementation of plans;

- protection of property;

- reliability and Comprehensiveness of information and accounts;

- abidance to commitments;

- risk management.

\footnotetext{
${ }^{6}$ It is worth noting that since 1999 Lithuania had a "Dusk Commission" (lith. Saulelydžio komisija) which analyses the institutional setup of the national bureaucracy and pus forwards suggestions to reform their organization. Their latest report presents and overview of public organizations. But by no means it is complete.

${ }^{7}$ NOTE: Laws and regulations mentioned here and elsewhere in the paper are not presented in the refferences list. They and their various editions can be found in the official registry of legal acts at: http://tar.tic.lt/.
} 
The long list from Lithuanian regulation comes close to a more concise academic list or purposes of organizational control:

- efficiency and effectiveness;

- trustworthiness of accounts;

- legality (Leitch 2008).

We can claim that the similarity of Lithuanian prescriptions to persons and agencies that exercise some form of control to Leitch's (2008) take on things seem to reconcile the "national" and "budgetary" interpretation of the state. But this we can claim has the potential to lead to even greater complexity of control, where all processes in the public sector end up being controlled times over from different perspectives. Even without such a consideration individual public sector organizations face more outside control that those in the private sector. And the problem is aggravated by the fact that these may follow different philosophies of what constitutes the proper functioning of organization (See Figure 3).

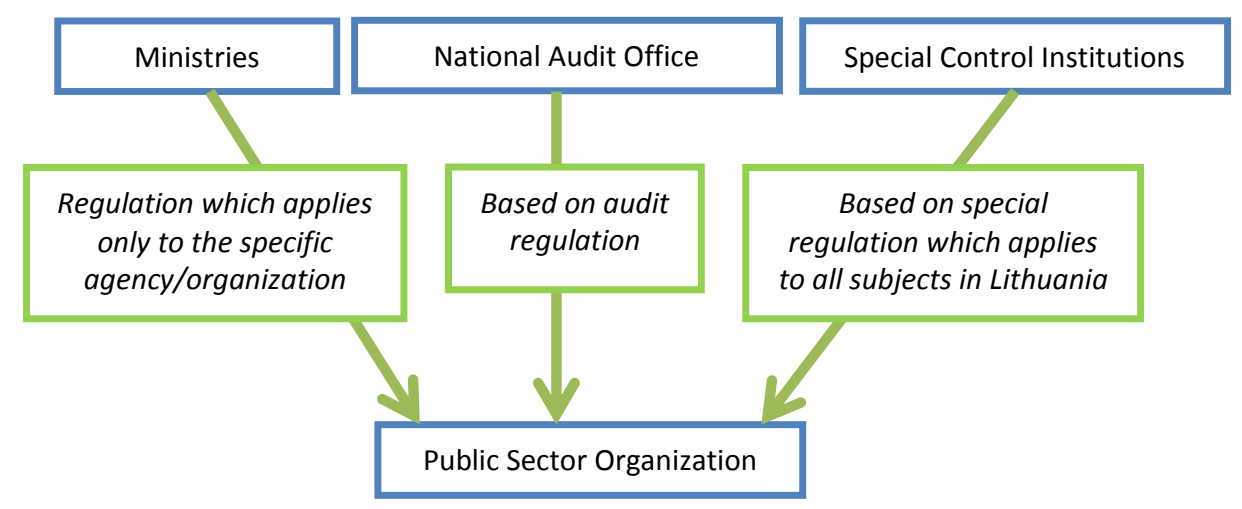

Fig.3. External control of public sector organizations

Source: developed by author

There is controversy whether it is possible to reconcile control mechanisms implicit in different management philosophies. Leitch (2008) suggests there is a fundamental contradiction between quality management and internal control philosophies. The first aims to minimize the impact of the human factor by continuously increasing and updating standardization, whereas the other identifies humans as the core of the organization and tries to minimize abuse, while not punishing for mistakes which are seen as an engine of growth (Leitch 2008). But in the Lithuanian public sector we can observe attempts to follow multiple control philosophies simultaneously. Notably, this is done by different agencies and managed as projects. Since 2005 Ministry of Internal Affairs has been implementing a monitoring system for organizations which have adopter the Common Assessment Framework (CAF), which is recommended by EUPAN. The CAF is closely related to quality management and the Ministry has a dedicated unit to conduct the monitoring. On the other hand since 2009 the right-wing coalition in government has approved the $\mathrm{VORT}^{8}$ project in an attempt to create a results-based governance model. This was implemented by the Prime Minister Office. However this project seems to be stagnating since the election brought center-left parties to power in 2012.

To add to the above in terms of internal control the entire burden of responsibility lies on directors of when trying to achieve all of the aims of control. This includes avoidance of illegality (law of internal control and audit) and evaluation civil servants performance (Government regulation on civil servants performance evaluation) meaning that managers in public organizations face a bureaucratic mechanism which makes entrepreneurship within the public sector difficult to promote. Also Lithuania remains a recipient of EU structural and cohesion support, which is often administered by various agencies and the process of accountability for this support; once the project goes ahead are very rigid (for an overview see Molle 2007).

Given all that is said we can attempt to describe the concept and major features of the Lithuanian public sector control:

- hierarchy within public agencies where the director has the ultimate power in terms of management and responsibility in terms of control;

${ }^{8}$ VORT in Lithuanian stands for Development of Results-based Governance (lith.Valdymo, orientuoto ị rezultatus, tobulinimas). 
- in term of intra-organizational control only internal audit and financial accountability are expressly prescribed, otherwise agency directors have broad discretion about what control mechanisms they instated;

- external audits (performed by non-state auditors) in the public sector are mandatory only in cases where EU funds are involved;

- National Audit Office duplicates the work of municipality auditors;

- there is no expressly defined concept of control in Lithuania regulation leading to apparent arbitrariness of setting control agency accountability to one or the other branch of government. There is a tendency, however, to make agencies responsible for protecting citizens' rights accountable to the parliament or the President, while agencies responsible for supervision that the public and businesses follow specialized laws, rules and regulations accountable to the government (usually at the ministry level);

- there are three types of control agencies: services, inspections, and commissions. Their naming does influence their legal status, usually these organizations are regulated by special laws. Their financial autonomy varies significantly;

- the court system ought to be considered a control subsystem in Lithuania, especially in light of it discretionary powers to determine the content of the public interest;

- the function of National Audit Office is primarily budget supervision. Performance audit is usually seen as consultative (Tumènas 2010).

- MP's have a constitutional right to directly exercise control over the Cabinet through a mechanism of parliamentary supervision (Kalinauskas 2011).

\section{The implications for pro-entrepreneurial policy}

Bureaucracy as M. Weber put it is the "Iron Cage" of modernity (Kim 2004). In the Lithuanian experience since late 1990's where we can trace two political narratives of how to create the public sector control mechanism seems to illustrate that this conclusion is still relevant. Of the three interpretations of the state we presented, two are in wide use when advocating policy. And in the development of the Lithuanian public sector control mechanism it had an effect of increasing levels of bureaucracy, because the two control mechanisms require agencies that are being controlled to adhere to both and thus using up more recourses and experiencing legal uncertainties. The fact that internal organizational management depends highly on the discretion of agency directors in such a climate acts to increase bureaucratic behaviour, not the contrary. The underlying reason for this that in the Lithuania political decisions of the parliament always trump strategic planning documents, making them impossible to use as tools for the improvement of governance, at best they ease data collection for monitoring organizations. Yet, Lithuanian state control towards businesses is far less inflexible. Lithuanian governments over the past two decades have embarrassed the Reagan-Thatcher style of economic policy irrespective of their ideology creating a dynamic economy (Norkus 2008). This arguably is rather favourable to entrepreneurship. The question we need to address now is this: would a more consorted effort to increase entrepreneurship within the public sector be beneficial to private entrepreneurship. Lithuania has so far failed to run its agencies as businesses and to some extent it is worth asking whether that is at all possible (see e. g. Drechsler 2005). But if it is, it also begs to ask whether that is desirable. Maybe instead of increasing entrepreneurship in society we will risk crowding out the genuine entrepreneurs with bureaucrats who have the option of falling back on the states' recourses which would give them a competitive advantage. Answering this is a difficult task. If we embrace the views of Lane (2001) and the "budgetary" interpretation of the state entrepreneurship in the public sector is a positive thing. But if we view it from the perspective of the "field" it appears that promoting entrepreneurship in the public sector is bound to add another layer of complexity to the workings of the public sector. And for things to go along we simply would end up creating another niche for middle-men between the state and the entrepreneur. And this, history tells us, is not sustainable.

\section{Conclusions}

Lithuanian regulation defines control on multiple levels. These can be separated into two groups. Intraorganizational control and Extra-organizational control. At intra-organizational level the organizations management has broad discretion to setup control mechanisms. However, at the extra-organizational level a complex and often contradictory control mechanism limit the utility of such autonomy. The extra- 
organizational control can be further subdivided into control mechanisms which by their ethos serve society/parliament and their function is to safeguard democracy. These include the ombudsman, national audit office and law enforcement agencies. The other group of control institutions are usually considered part of the executive and are tasked with controlling "society" based on special regulation.

To make better sense of how Lithuania ended up having such a control mechanism we presented three interpretations of the state. Lithuanian Constitution gives primacy to one of them - "national". However, during the process of post-communist transition Lithuanian institutions increasingly adopted a "budgetary" interpretation of the state. The result was that public sector organizations now need to account at both level. This means, paradoxically, that by attempting to reform the way motivation and control is conducted in the public sector bureaucracy becomes more entrenched. This paradox is explained by the "field" interpretation of the state, which suggests, that creating new institutions does not automatically undermine the old ones.

We can conclude that Lithuanian government without a consensus (this includes the political opposition as well) cannot hope to create a cohesive control mechanism in the public sector which would promote entrepreneurship at the same time minimizing the possibilities for abuse. The current complex system of public sector control nonetheless, does not necessarily mean that this translates into difficulties to the private sector, unless future reforms of control continue increasing in their complexity.

\section{References}

Bileišis, M. 2012a. Empowering institutions: a case for connecting business and the academe through phronesis, Journal of security and sustainability issues: international entrepreneurial perspectives and innovative outcomes 1(3): 177-185. DOI: http://dx.doi.org/10.9770/jssi/2012.1.3(3)

Bileišis, M. 2012b. Viešasis valdymas ar valdysena? Lietuviškasis kontekstas [Public Governance or 'Governance'? The Lithuanian Context], Viešoji politika ir administravimas [Public Policy and Administration] 11(2): 314-330.

Castells, M. 2006. Tapatumo galia. Informacijos amžius: ekonomika, visuomenè ir kultūra, 2t. Kaunas: Poligrafija ir informatika.

Drechsler, W. 2005. The Re-Emergence of "Weberian" Public Administration after the fall of New Public Management: The Central and Eastern European Perspective, Halduskultuur/Administrative Culture 6: 94-108.

Eagle, M. 2008. Politics: An Introduction to Democratic Government. Third edition. Toronto: Broadview Press.

Grenfell, M. 2008. Pierre Bourdieu: Key Concepts. Durham, GBR: Acumen Publishing.

Hood, Ch. 1991. A Public Management for All Seasons? Public Administration 69(1): 3-19.

Kalinauskas, G. 2011. Parlamentine kontrolè. II dalis: Praktika [Parliamentary Control, Part 2: Practice]. Vilnius: Registrų centras.

Kim, S. H. 2004. Max Weber's Politics of Civil Society. West Nyack, NY, USA: Cambridge University Press.

Lane, J. E. 2001. Viešasis sektorius: sq̨vokos, modeliai ir požiūriai. Vilnius: Margi raštai.

Leitch, M. 2008. Intelligent Internal Control and Risk Management. Abingdon, GBR: Ashgate Publishing Group.

Midgal, J. S. 2001. State in Society: Studying How States \& Societies Transform and Constitute One Another. Port Chester, NY, USA: Cambridge University Press.

Molle, W. 2007. European Cohesion Policy. Abington: Routledge.

Morrison, K. 2006. Marx, Durkheim, Weber: Formations of Modern Social Thought. London: SAGE Publications.

Norkus, Z. 2008. Kokia demokratija, koks kapitalizmas? Pokomunistine transformacija Lietuvoje lyginamosios istorinès sociologijos požiūriu [What Democracy, What Capitalism? Post-Communist Transformation of Lithuania from the Perspective of Historical Comparative Sociology]. Vilnius: Vilniaus universiteto leidykla.

Palombella, G. 2010. The Rule of Law as an Institutional Ideal, in Morlino, L. and Palombella, J. (Eds.). Rule of Law and Democracy: Inquiries into Internal and External Issues. Boston, MA, USA: Brill Academy Publishers, 3-38.

Petrovic, M. 2013. The Democratic Transition of Post-Communist Europe: In the Shadow of Communist Differences and Uneven EUropeanisation. Basingstoke: Palgrave Macmillan.

Rao, P. S.; Kumar, V. T. 2010. Management Theory and Practice: Text and Cases. Mumbai, IND: Global Media. 
Tsai, K. S. 2007. Capitalism without Democracy - The Private Sector in Contemporary China. Ithaca, N.Y.: Cornell University Press.

Tumėnas, A. 2010. Valstybiniu organizaciju reformu ir pokyčiu teorine analyze [Theoretical Analysis of Government Organization Reforms and Change]. Daktaro disertacija. Vilnius: Mykolo Romerio Universitetas.

Mantas BILEIŠIS - PhD, associate professor at the Institute of Public Administration at Mykolas Romeris University. Research interests: Institutional theory, public governance, development of the public sector. 